HELMINTHOLOGIA, 55, 1: 1 - 11, 2018

\title{
Review
}

\section{Helminth therapy: Advances in the use of parasitic worms against Inflammatory Bowel Diseases and its challenges}

\author{
M. MARUSZEWSKA-CHERUIYOT*, K. DONSKOW-ŁYSONIEWSKA, M. DOLIGALSKA
}

Department of Parasitology, Faculty of Biology University of Warsaw, Miecznikowa 1, 02-096 Warsaw, Poland, E-mail: mmaruszewska@biol.uw.edu.pl

\section{Article info}

Received April 4, 2017 Accepted August 31, 2017

\begin{abstract}
Summary
Development of modern medicine and better living conditions in the 20th century helped in reducing a number of cases of infectious diseases. During the same time, expansion of autoimmunological disorders was noticed. Among other are Inflammatory Bowel Diseases (IBD) including ulcerative colitis and Crohn's disease which are chronic and relapsing inflammation of the gastrointestinal tract. Absence of effective treatment in standard therapies effects the search for alternative opportunities. As per hygienic hypothesis increasing number of cases of autoimmune diseases is as a result of reduced exposure to pathogens, especially parasites. Thus, one of the promising remedial acts against $\mathrm{IBD}$ and other allergic and autoimmune disorders is "helminth therapy". Cure with helminths seems to be the most effective therapy of IBD currently proposed. Helminth therapy focuses on advantageous results that have been obtained from the clinical trials, but its mechanisms are still unclear. Explanation of this phenomenon would help to develop new drugs against IBD based on helminth immunomodulatory molecules.
\end{abstract}

Keywords: helminth therapy; Heligmosomoides polygyrus; Inflammatory Bowel Diseases; ulcerative colitis

\section{Introduction}

Helminths have co-evolved with their hosts over millions of years to arrive at a form of mutualism where both the host and the parasite derive some benefit from their relationship. The immunosuppression and immunoregulation induced by helminths is obviously beneficial for the parasite: it prevents the parasite being killed or expelled and improves its fitness; it also inhibits inflammatory reactions and otherwise innocuous antigens, thus benefitting the host by preventing local and peripheral pathologies generated against it (Barthlott et al., 2003). The absence of effective forms of treatment and the unsatisfactory causal effects of conventional therapies for autoimmune diseases has aroused interest in new forms of treatment (Chandrashekara, 2012). The key aspects of research into helminth therapy $(\mathrm{HT})$ and helminth-derived product therapy (HDPT) concern the use of live helminths as treatment, as well as the characterization of the key molecules responsible for immunomodulation. These could be used as drugs to control inflammation and autoimmune diseases. HT currently seems to be the most effective therapy for autoimmune disorders (Wilson \& Maizels, 2004); however, live nematode therapy remains undoubtedly controversial, especially as the mechanism of disease prevention and inhibition is unknown (Erb, 2009). In addition, the therapeutic effects of helminths are undoubtedly complex, and for this reason, the use of individual immune-active components isolated from nematode products as potential drugs is not as meaningful as previously believed.

\footnotetext{
$\bar{*}$ - corresponding author
} 


\section{Inflammatory Bowel Disease (IBD) Problems}

Inflammatory Bowel Disease (IBD), comprising Crohn's disease (CD) and ulcerative colitis (UC), is a chronic, idiopathic, and relapsing inflammation of the gastrointestinal tract. This disorder is most common in young adults, but can also develop in childhood and old age. The worldwide incidence rate of $C D$ varies between $0.1-16 / 100,000$ persons worldwide, while UC is more common and varies greatly between $0.5-24.5 / 100,000$ persons, with the prevalence rate of IBD reaching up to $400 / 100,000$ persons. However, the incidence and prevalence of the disorder are probably higher because despite the existing Montreal classification of IBD (Satsangi et al., 2006), precise diagnosis is limited by the lack of gold standard criteria for identification, resulting in inconsistent case ascertainment and disease misclassification (Lakatos, 2006; Molodecky et al., 2012).

The inflammation in UC is characterized by superficial ulcerations, granularity and a distorted vascular pattern. Histological features include an expansion of the lamina propria with inflammatory cells and crypt abscesses. There are usually no fistulae or granulomas: the typical histopathologic features of Crohn's disease. As a consequence, the symptoms of UC are a progressive loosening of bloody stools, rectal bleeding, diarrhea, tenesmus with cramping abdominal pain and a severe urgency to have a bowel movement up to 20 times a day (Brandtzaeg et al., 1997).

There is no effective treatment for colitis and therapy is based on encouraging long-term remission with anti-inflammatory medications. The four major classes of medication used today to treat UC are aminosalicylates, steroids, immune modifiers (azathioprine, 6-MP, and methotrexate) and antibiotics administered orally or rectally; however, all have restrictions, including side effects, refractoriness or unresponsiveness. In one-quarter to one-third of patients with UC, medical therapy is not completely successful or complications arise. Complications of UC can include bleeding from deep ulcerations and rupture of the bowel (Leitner \& Vogelsang, 2016). Patients are at increased risk of colonic epithelial dysplasia and carcinoma, with an age-specific risk that is at least three times greater than that in the general population. As the risk of developing cancer increases in patients with long-term UC (7 to 10 years) with a rate of approximately $0.5-1 \%$ per year, endoscopic surveillance examinations are performed annually and surgery offered for patients with ileal pouch-anal anastomosis. Over the long term, up to $25 \%$ of those with UC will require surgery (Bernstein, 2001).

Although knowledge of UC dates back to the 19th Century, the pathogenic cause remains unknown. Its pathogenesis is believed to be associated with a deregulated proinflammatory response to commensal gut bacteria; it is restricted to the epithelial mucosa of the colon in an even and continuous distribution not related to any intestinal infection. Recent genetic studies have identified about 163 genes which are crucial in the development of IBD; most of them are common between Crohn's disease and ulcerative colitis
(Cleynen et al., 2016). In addition, several environmental risk factors are known to be associated with IBD disease cases including diet, intestinal microbiota composition, medication and vaccination, physical exercise, stress, appendectomy, breastfeeding, air pollution and heavy metals, as well as exposure of vitamin $D$ to UV (Niewiadomski et al., 2016). Smoking has also been proposed to have an influence on the pathogenesis of IBD (Samuelsson, 1976). A sizable proportion of previous research indicates that cigarettes increase the chance of developing Crohn's disease despite protecting against the development of colitis. The mechanism of this phenomenon remains unclear, but can be consequence of changes in the composition of the intestinal microbiota (Biedermann et al., 2013).

There is a high probability that the increase in prevalence of IBD seen in the 20th Century is associated with the industrial revolution in Europe and North America. Regional variation has also been observed, insofar as there is large difference in the numbers of cases of autoimmunological diseases, including IBD, between Western and Eastern countries: Based on a review of data from 1920 - 2008, the highest annual incidence of UC was 24.3/100,000 person-years in Europe and 19.2/100,000 person-years in North America compared to $6.3 / 100,000$ person-years in Asia and the Middle East. The highest reported prevalence of UC was observed in Europe (505/100,000 persons) and North America (249/100,000 persons). It has been found that $60 \%$ of documented studies of UC report an increasing number of incidences (Molodecky et al., 2012). Other reports indicate that children who have moved from countries with a low IBD incidence to countries with a high incidence have the same probability of developing IBD as the children living in the high-incidence regions (Brobert et al., 1992; Li et al., 2011).

Hence, environmental factors appear to play a role in the development of IBD, and differences in lifestyle and medical level are reflected in the results of studies. This trend has been attributed to the Hygienic Hypothesis, a term first used by Strachan (1989). The Hygienic Hypothesis implies that a lack of immune system actuation in adulthood occurs as a result of maintaining high cleaning standards and avoiding contact with microorganisms during childhood, a potential consequence of which can be the development of a range of immunological disorders, including IBD and allergic diseases. Contact with pathogens is influenced by many factors, including education level, diet, antibiotics and vaccinations, medical and deistical admission, sharing bedrooms or even having pets (Leong et al., 2016). If permanent contact with bacteria and viruses is maintained, interaction with multicellular parasites such as nematodes or tapeworms can be eradicated thanks to extensive access to antihelminth drugs and adherence to hygiene rules. In United States schoolchildren, the prevalence of hookworm fell from $65 \%$ in 1910 to fewer than $2 \%$ in 1980 (Kappus et al., 1994). The co-evolution of host and parasite resulted in the development of a very complicated mechanism for avoiding the host immunological system, thus increasing the potential for the parasite to 
survive and reproduce: Gastrointestinal nematodes cause chronic infection and induce immunosuppression. Such regulation of the immune response by the parasite also offers positive benefits for the host organism: the nematodes control the immunity caused by infection, as well as the responses to various non-nematode antigens (Barthlott et al., 2003). However, a strong inflammation response can result in damage to the infected area (Maizels et al., 2004). Such deprivation of contact with multicellular parasites observed in Western countries resulting from their high level of hygiene can affect the immunological balance by forcing inequalities in the host-parasite arrangement constructed over millions of years. These phenomena result in the creation of new variants of the Hygienic Hypothesis, such as the Lost Friends Theory or the Biome Depletion Theory. With these theories in mind, it seems like the best option in allergies and autoimmunological disorders treatment is reconstruction of human biome (Bilbo et al., 2011).

\section{Immunological Response in the Intestine}

The mucosal membrane of the intestine plays a crucial role in the immunological system. The digestive tract is in constant contact with both commensal and pathogenic microorganisms (Macdonald $\&$ Monteleone, 2005). The immune system must therefore be able to control symbiotic bacteria and tolerate them, while being able to eradicate pathogens. During colitis, the gut epithelial barrier is dysfunctional (McGuckin et al., 2009), and the recognition and response to multiple antigens, commensals or nutrients results in local inflammation of the colon. A hypothesis proposed by Shorter et al. (1972) presents that IBD, including colitis, occurs as a result of the establishment of a state of hypersensitivity to the bacterial antigens which are normal components of the intestinal microflora. It is known that other factors further aggravate epithelial-associated dysfunction, which then develops into chronic inflammation of the gastrointestinal tract. Nonetheless, the intestinal microbiota is crucial for the development of IBD and influences the mucosal immune response during active disease.

In healthy patients, the immune system associated with the mucosal gut develops a tolerance to commensal microorganisms and food antigens. three types of Antigen-Presenting Cells (APC), viz. dendritic cells (DC), macrophages and $B$ lymphocytes, play a fundamental role in this process (Mann \& Li, 2014). DC are able to stimulate primary lymphocyte $T$ cells and differentiate into regulatory T cells (Treg) (Rescigno \& Sabatino, 2009), both macrophages and B-cells maintain the survival of Treg, while also secreting interleukin 10 (IL-10) and transforming growth factor $\beta$ (TGF- $\beta$ ); thus they maintain immune homeostasis and tolerance (Mann \& Li, 2014; Hadis et al., 2011).

In colitis, antigens emerge from pathogens, food and commensal bacteria which cause intestinal inflammation as a result of the activity of innate immune cells. DC and macrophages secrete proinflammatory cytokines; tumor necrosis factor a (TNF- $\alpha$ ), IL-6 and IL-1 $\beta$. In the adaptive immune response, T helper type 1 cells
(Th1) are activated, resulting in strong production of proinflammatory cytokines: interferon $\mathrm{y}$ (IFN-ץ), TNF-a and IL-17A (Cader \& Kaser, 2013). The existence of a parasite in the host results in Th2 response activation with the production of IL-3, IL-4, IL-5, IL-9, IL-10 and IL-13. In addition, induction of increased populations of basophils, mast cells, eosinophils and alternatively-activated macrophages, together with immunoglobulin $\mathrm{G} 1\left(\lg _{1}\right), \lg \mathrm{G}_{4}$ and $\lg \mathrm{E}$, are characteristic in cases of multicellular parasite infection (Allen \& Maizels, 2011; Maizels et al., 2012).

However, the immunoregulatory abilities of helminths inhibit the immunological reaction by the activation of regulatory $T$ lymphocytes (Taylor et al., 2012). Higher levels of IL-10 and TGF- $\beta$ secretion suppress Th1 and Th2 cell activity, consequently protecting both the parasite against expulsion and the host against damage to the tissues caused by the strong inflammatory reaction (Khan \& Fallon, 2013). Immunosuppression is specific to helminths but also antigens not associated with infection and hence could be employed in anti-inflammation therapy (Finlay et al., 2014).

\section{Colitis Helminth Therapy in Animal Models}

\section{Colitis induction methods}

Before helminth therapy can be introduced in IBD patients, it is necessary to understand the mechanism of their immunoregulatory abilities. Elliott and colleagues (2000) propose the hypothesis that exposure to helminths can prevent IBD and highlighted the need to formulate a novel chronic intestinal inflammation model for humans. Since then, a few models of colitis induction have been used in rodents to identify a cure for IBD, the main ones being chemically-inducible models, spontaneous models, genetically-modified models and adoptive transfer models (Witrz \& Neurath, 2007). Mucosal immune system dysfunction and display of disease manifestation can be achieved in three ways: through defects in epithelial integrity and permeability, deficiency in innate immune cells or by deficiency in adaptive immune cells. These effects can be achieved chemically using dinitrobenzene or trinitrobenzene sulfonic acid (DNBS/TNBS)-inducted colitis (Morampudi et al., 2014) or dextran sulfate sodium (DSS)-inducted colitis (Chassaing et al., 2015), resulting in mechanical dysfunction of epithelial integrity. Alternatively, IL-10 knockout (IL-10-/-) mice can be used (Keubler et al., 2015), which develop spontaneous chronic inflammation in the intestine, i.e. T cell transfer colitis, due to a lack of the main immune regulatory interleukin. In this case, the disease occurs as a result of a deficiency of T regulatory cells (Witrz \& Neurath, 2007).

\section{Trematoda}

Another issue concerns the variety of species of parasite used in the animal models. Three classes of parasite can be used, namely trematodes, cestodes and nematodes, referred to as helminths. One of the parasite genera belonging to the trematode Schistosoma seems to be a promising model for HT. Eliot et al. (2003) first published results of TNBS-inducted colitis mice infected by 
Schistosoma mansoni eggs which showed attenuation of intestinal inflammation manifestations. A similar effect has been already demonstrated in TNBS-inducted colitis rats after administration of S. mansoni larvae (Morels et al., 2004). In a different study, infection of mice with $S$. mansoni larvae protected against the manifestation of DSS colitis with macrophage participation (Smith et al., 2007). The influence of $S$. japonicum eggs demonstrated a preventive outcome on TNBS-inducted colitis in mice (Zhao et al., 2009; Xia et al., 2011). In another study, infection with S. mansoni larvae of DSS-inducted colitis mice resulted in reduced manifestations and lower levels of Th1 and Th2 cytokines (Bodammer et al., 2011) (Table 1).

\section{Cestoda}

One of the cestode class, Hymenolepis diminuta is also successfully used a model of colitis parasite therapy. Preventive and curative treatment of tapeworm larvae resulted in normalization of colonic ion transport in DSS-inducted colitis mice. No differences in histological or cytokine level were observed (Reardon et al., 2001). Hunter et al. (2005) demonstrated a reduction of DNBS-inducted colitis symptoms and higher levels of IL-10 and IL-4 in a mouse model. The same team showed increased levels of Th2 and Treg response interleukins in a colitis model induced by oxazolone (Hunter et al., 2007). Elsewhere, infection with $\mathrm{H}$. diminuta larvae of DNBS-inducted colitis mice resulted in higher levels of Th2 and Treg, and a lower level of Th1 cytokines (Melon et al., 2010) (Table 1).

\section{Nematoda}

The most promising group of intestinal parasite seems to be the nematodes. Trichinella spiralis infection was found to protect mice from developing DNBS-inducted colitis (Khan et al. 2002). Another study a decade later reported attenuation of DSS-inducted colitis by Trichinella papuae larvae (Adisakwattana et al., 2013). Elsewhere, Trichuris trichiura eggs restored mucosal barrier functions and reduced overall bacterial attachment to the intestinal mucosa in idiopathic chronic diarrhea in macaque monkeys (Broadhurst et al., 2012). The majority of investigations about mechanisms of helminth therapy in human IBD is focused on the gastrointestinal nematode Heligmosomoides polygyrus. This parasite of mice, with a simple and short life cycle, is an excellent model of human infection with Necator americanus (Monroy \& Enriquez, 1992). Both nematodes have been phylogenetically placed in the order Strongylida (Gouy et al., 2011). Another advantage of using H. polygyrus is that its laboratory breeding procedure is uncomplicated. Different tribes of mice react differently to $H$. polygyrus infection, which enables the investigation of the influence of genetic conditioning to the host immunological response. The inflammatory response is reduced during $H$. polygyrus infection, thus demonstrating the suitability of the nematode model in IBD suppression process.

To date there have been numerous reports demonstrating that $H$. polygyrus infection is an effective therapy for colitis. Elliot et al.
(2004) first demonstrated that $H$. polygyrus larvae can treat colitis in IL-10-/- mice, and later demonstrated suppression of mucosal $\mathrm{IL}-17$ production in the same model (Elliott et al., 2008). Infection by $H$. polygyrus larvae in IL10-/- mice with T cell transfer colitis effected induction of CD8+ regulatory cells (Metwali et al., 2006). Promising results have been achieved on the same model, showing that $\mathrm{DC}$ plays a crucial role in the regulatory immune response in colitis (Hang et al., 2010; Blum et al., 2012). Studies on TNBS-inducted colitis mice revealed attenuation of the disease with mast cell infiltration following infection by $H$. polygyrus larvae (Setiawan et al., 2007; Sutton et al., 2008). Our own previous studies found infection with $H$. polygyrus larvae to have a curative effect on DSS-inducted colitis with macrophage infiltration and decreased levels of MOR1, POMC and $\beta$-endorphin observed in the colon (Donskow-Łysoniewska et al., 2012). Administration of the same larvae to antigen-driven colitis mice also resulted in protection from disease with the induction of Foxp3 ${ }^{+}$Treg cells (Leung et al., 2012).

A treatment effect is not achieved in every model of intestinal inflammation. Investigations in mice with Citrobacter rodentium-induced colitis infected with $H$. polygyrus larvae found that DC activation and IL-10 production impaired the host response to $C$. rodentium (Chen et al., 2005; Chen et al., 2006). Similarly no curative effect was observed in mice with TGF- $\beta R$ II DN colitis caused by blocking the effect of TGF- $\beta$ on T cells; the findings showed that TGF- $\beta$ signaling to T cells can play an essential role in the regulatory abilities of helminths (Ince et al., 2009).

All studies clearly show that various species of intestinal parasites have curative and protective effects in animal models. The reports also give an insight into the mechanisms of IBD treatment in humans with helminths. However, these achievements are closely dependent on the method of inducing intestinal inflammation, as well as the choice of parasite species (Table 1).

\section{Therapeutical Potential of Intestinal Helminths}

The most common genera of nematodes distributed in human digestive track are Ascaris, Trichuris (whipworm), Necator and Ancylostoma (hookworms). Two species of which, Trichuris suis and Necator americanus, have been investigated in clinical examinations of UC and CD patients. Although $T$. suis is a natural parasite in the caecum and colon of pigs, it can also infect other hosts, including humans; however, the worms can only survive in the human digestive tract for a few weeks (Helmby, 2015).

There is discrepancy in host species and deficiency in inflammatory response for the parasite marked $T$. suis for the most promising nematode for human IBD therapy. The initial results of small clinical studies of IBD treatment with T. suis were published in 2003 by Summers et al. A group of UC and CD patients received a single oral dose of 2500 live $T$. suis eggs, and were then monitored every 14 days for 12 weeks. A second group of patients received the same administered dosage every 21 days for 28 weeks. After 
Table 1. Summary of helminth therapy with live parasites in animal models in IBD.

\begin{tabular}{|c|c|c|c|}
\hline Author & $\begin{array}{l}\text { Model of colitis } \\
\text { induction }\end{array}$ & Parasite class / species & Main outcomes \\
\hline Eliot et al., 2003 & TNBS & $\begin{array}{l}\text { Trematoda / Schistosoma } \\
\text { mansoni }\end{array}$ & $\begin{array}{l}\text { Th1 response reduction, Th2 and Treg } \\
\text { response induction }\end{array}$ \\
\hline Morels et al., 2004 & TNBS & Trematoda / S. mansoni & Th2 response induction \\
\hline Smith et al., 2007 & DSS & Trematoda / S. mansoni & Macrophage participation \\
\hline Zhao et al., 2009 & TNBS & Trematoda / S. japonicum & Th1 response reduction \\
\hline Xia et al., 2011 & TNBS & Trematoda / S. japonicum & $\begin{array}{l}\text { Lower intestinal bacterial translocation } \\
\text { frequency }\end{array}$ \\
\hline Bodammer et al., 2011 & DSS & Trematoda / S. mansoni & Th1 and Th2 response reduction \\
\hline Reardon et al., 2001 & DSS & $\begin{array}{l}\text { Cestoda / Hymenolepis } \\
\text { diminuta }\end{array}$ & No changes in response noticed \\
\hline Hunter et al., 2005 & DNBS & Cestoda / H. diminuta & Th2 and Treg response induction \\
\hline Hunter et al., 2007 & Oxazolone & Cestoda / H. diminuta & Th2 and Treg response induction \\
\hline Melon et al., 2010 & DNBS & Cestoda / H. diminuta & $\begin{array}{l}\text { Th2 and Treg response induction and } \\
\text { Th1 response reduction }\end{array}$ \\
\hline Broadhurst et al., 2012 & $\begin{array}{l}\text { Idiopathic chronic diarrhea } \\
\text { in macaques monkeys }\end{array}$ & $\begin{array}{l}\text { Nematoda / Trichuris } \\
\text { trichiura }\end{array}$ & $\begin{array}{c}\text { Mucosal barrier functions restored } \\
\text { and overall bacterial attachment to the } \\
\text { intestinal mucosa reduced }\end{array}$ \\
\hline Khan et al., 2002 & DNBS & $\begin{array}{l}\text { Nematoda / Trichinella } \\
\text { spiralis }\end{array}$ & Th2 response induction \\
\hline Adisakwattana et al., 2013 & DSS & Nematoda / T. papuae & $\begin{array}{l}\text { Th2 response induction and Treg } \\
\text { response changes }\end{array}$ \\
\hline Elliot et al., 2004 & IL-10-/- & $\begin{array}{c}\text { Nematoda / } \\
\text { Heligmosomoides polygyrys }\end{array}$ & $\begin{array}{l}\text { Th1 response reduction and Treg } \\
\text { response induction }\end{array}$ \\
\hline Chen et al., 2005 & Citrobacter rodentium & Nematoda / H. polygyrys & STAT 6-mediated mechanism \\
\hline Chen et al., 2006 & Citrobacter rodentium & Nematoda / H. polygyrys & $\begin{array}{l}\text { CD11c+ dendritic cells activation and } \\
\text { IL-10 production }\end{array}$ \\
\hline Metwali et al., 2006 & IL10-/- T cell transfer & Nematoda / H. polygyrys & CD8+ regulatory cells induction \\
\hline Setiawan et al., 2007 & TNBS & Nematoda / H. polygyrys & $\begin{array}{l}\text { Th1 response reduction and Treg } \\
\text { response induction }\end{array}$ \\
\hline Elliott et al., 2008 & IL-10-/- mice & Nematoda / H. polygyrys & Suppression of mucosal IL-17 production \\
\hline Sutton et al., 2008 & TNBS & Nematoda / H. polygyrys & mast cells infiltration \\
\hline Ince et al., 2009 & TGF-ßRII DN & Nematoda / H. polygyrys & $\begin{array}{c}\text { A role of TGF- } \beta \text { signaling to } T \text { cells in } \\
\text { regulatory response }\end{array}$ \\
\hline Hang et al., 2010 & IL10-/- T cell transfer & Nematoda / H. polygyrys & $\begin{array}{l}\text { A role of dendritic cells in regulatory } \\
\text { immune response }\end{array}$ \\
\hline Blum et al., 2012 & IL10-/- T cell transfer & Nematoda / H. polygyrys & Induction of tolerogenic dendritic cells \\
\hline $\begin{array}{c}\text { Donskow-Łysoniewska et } \\
\text { al., } 2012\end{array}$ & DSS & Nematoda / H. polygyrys & $\begin{array}{l}\text { Macrophage infiltration and MOR1, } \\
\text { POMC, } \beta \text {-endorphin increased levels }\end{array}$ \\
\hline Leung et al., 2012 & Antigen driven & Nematoda / H. polygyrys & Induction of Foxp3 $3^{+}$Treg cells \\
\hline
\end{tabular}


Table 2. Summary of clinical trials of helminth therapy with live parasites in IBD.

\begin{tabular}{|c|c|c|}
\hline Author & Scheme of trial & Results \\
\hline $\begin{array}{l}\text { Summers } \\
\text { et al., } 2003\end{array}$ & $\begin{array}{l}\text { Single or repeated dose of } 2500 \text { live eggs of } T \text {. suis administered every } \\
\qquad 3 \text { weeks for } 28 \text { weeks to } 3 \text { UC and } 4 \text { CD patients. }\end{array}$ & $\begin{array}{l}\text { No side effects. } \\
\text { Remission noticed on every patient administered } \\
\text { with repeated dose. }\end{array}$ \\
\hline $\begin{array}{l}\text { Summers } \\
\text { et al., } 2005 a\end{array}$ & $\begin{array}{l}\text { Repeated dose of } 2500 \text { live eggs of } T \text {. suis administered every } 3 \text { weeks } \\
\text { for } 24 \text { weeks to } 29 \text { CD patients. }\end{array}$ & $\begin{array}{l}\text { No side effects. } \\
\text { Remission noticed on } 72.4 \% \text { of patients. }\end{array}$ \\
\hline $\begin{array}{l}\text { Summers } \\
\text { et } a l, 2005 b\end{array}$ & $\begin{array}{l}\text { Repeated dose of } 2500 \text { live eggs of } T \text {. suis administered every } 2 \text { weeks } \\
\text { for } 12 \text { weeks to } 54 \text { UC patients. }\end{array}$ & $\begin{array}{l}\text { No side effects. } \\
\text { Remission noticed on } 43.3 \% \text { of patients. }\end{array}$ \\
\hline $\begin{array}{l}\text { Sandorn } \\
\text { et al, } 2013\end{array}$ & $\begin{array}{c}\text { Single dose of } 500,2500 \text { or } 7500 \text { live eggs of } T \text {. suis administered } \\
\text { to } 36 \text { CD patients. }\end{array}$ & $\begin{array}{l}\text { Every dose very well tolerated. } \\
\text { Quantity of dose has no influence on } \\
\text { gastrointestinal tract response. }\end{array}$ \\
\hline $\begin{array}{l}\text { Croese } \\
\text { et al, } 2006\end{array}$ & $\begin{array}{l}\text { Single or repeated dose of 25-50 L3 larvae of } N \text {. americanus } \\
\text { administered to } 9 \text { CD patients. }\end{array}$ & $\begin{array}{l}\text { Side effects: itching, enteropathy, eosinophilia. } \\
\text { Condition of majority of patient's improved. }\end{array}$ \\
\hline
\end{tabular}

Abbreviations: UC - ulcerative colitis, CD- Crohne Disease

accurate monitoring, no side effects were noticed and a further repeated dosage resulted in the improvement of all medicated patients (Summers et al., 2003). Similarly, in a second clinical trial, a repeated dose of 2500 viable $T$. suis eggs was given to 29 of $C D$ patients every 21 days for 24 weeks, and no adverse reaction was observed. After 24 weeks of therapy, $79.3 \%$ of patients responded to treatment and $72.4 \%$ were in remission, as evaluated based on Crohn's disease activity index (Summers et al., 2005a). A similar examination was conducted on 59 UC patients. A dose of $2500 \mathrm{~T}$. suis eggs or placebo was given every two weeks for 12 weeks: It was found that $42.3 \%$ of patients who received $T$. suis and $16.7 \%$ of those who received placebo responded, but only $10 \%$ of the first group and $4.2 \%$ of the second displayed remission, with no side effects to induction. The outcome was calculated based on UC disease activity index (Summers et al., 2005b).

Almost a decade after helminths were first demonstrated to have promising effects in IBD therapy in humans, Sandborn et al. (2013) demonstrated novel findings concerning the safety and tolerance of various doses of $T$. suis in clinical trials with patients with $C D$. The patients received one dose of $500,2500,7500$ T. suis eggs or placebo. They were then evaluated for 14 days, and then by telephone interview one, three and six months after receiving the dose. All doses, including the 7500-egg dose, was very well tolerated without any short or long-term adverse reactions (Sandorn et al., 2013). In the meantime, $N$. americanus has been proposed as an alternative for $T$. suis and studies have been carried out to investigate tolerance to infection and a number of other practical topics. Humans can be infected with $N$. americanus larvae third-stage (L3) by skin contact with contaminated soil. The adult worms are situated in small intestine of the host and can survive for five years, although expulsion of the parasite is possible with anthelmintic medicines. It is important to note that one consequence of infection is anemia caused by the helminth feeding on blood. In the experiment, CD patients were inoculated with a single or a repeated dose of $25-50$ infective larvae (L3). Despite a promising remission effect, the pre- sence of the worms yielded a mild itch, painful transient enteropathy and blood eosinophilia (Croese et al., 2006).

The outcomes of these studies clearly show the great potential of helminths in IBD therapy, and further study is needed in this area. While just one study has examined $N$. americanus, and side effects were observed, the parasite may still serve as a promising alternative for $T$. suis, especially since $N$. americanus is very well tolerated in CD therapy (Daveson et al., 2011; Croese et al., 2015). Live $T$. suis and the haematophagous hookworm $N$. americanus have been suggested as effective treatments for IBD, and three clinical trials have been initiated: NCT01040221; NCT01070498; NCT01413243 (Correale, 2014; Ruyssers et al., 2008). Nonetheless, a greater understanding of the mechanism by which inflammation is suppressed in the intestine by helminths is essential for further progress in clinical practice (Table 2).

\section{Challenges of Helminth Therapy}

During HT, the amelioration of symptoms was only seen when the helminth infection was present; removal of the parasites resulted in the remission of IBD pathology and the inhibition of immunomodulatory response (Fleming et al., 2011). Furthermore, many patients feel uneasy about receiving live worms for therapy. In addition, aside from the ethical concerns, there are many practical considerations that may reduce the efficacy of this approach. Nematode L4 larvae invade tissues, and even small numbers of hookworms can induce gastrointestinal or other tissue pain in the early stages of infection; they can also exhibit aberrant migration in the human host and influence the physiology of their respective niches. Live parasite infections result in the induction of danger signals and pro-inflammatory stimuli, thus leading to inflammation. Furthermore, in addition to the desired helminth immunomodulators, the host is exposed to the full spectrum of helminth-derived products including potent antigens, inflammatory stimuli and potentially disease-causing allergens. It is important to note that only 
the minimum number of larvae was used in the trial for safety reasons, and so potential clinical benefits may have been lost. In addition, as early infection is characterized by obvious symptoms that will reveal to patients whether they are in a placebo or treatment group, it is very difficult to conduct trials by incorporating proper placebo controls. Furthermore, helminths can influence drug efficacy by modulating the host immune response, and colonization may worsen other pathogenic infections in immunocompromised hosts (Correale, 2014).

Treatment with living nematodes therefore has clear disadvantages, and in order to survive for a long time in an adverse and aggressive environment, the nematodes may modify host-cell homeostasis and increase susceptibility to oncogenic transformation by secreting several soluble factors that interact with host cells (Packham \& Stevenson, 2005; Donskow et al., 2011; Donskow-Łysoniewska et al., 2013b). The factors secreted by helminths could be involved in neoplasma promotion and progression. Schistosoma haematobium, Spiromera mansonoides, Taenia taeniaformis, and T. solium, all have significant tumor-promoting activity (Herrera \& Ostrosky-Wegman, 2001). Excretory-secretory (ES) products from the small intestine nematodes Trichostrongylus vitrinus, $T$. colubriformis, Cooperia curticei, Nematodirus battus and the abomasal nematode Teladorsagia circumcincta have all been shown to produce over-proliferation in normal intestinal epithelial cells and/ or cell lines (Huby et al., 1995). Additionally, our study indicated that in live nematode therapy of colitis, the changes in the small intestinal milieu promote intestinal nematode larval adaptation and improve worm growth. The plasticity of the nematode proteome is a consequence of evolutionary adaptation which benefits the host by inhibiting inflammatory disease and also the parasite by increasing its survival (Donskow-Łysoniewska et al., 2013a) (Table 3).

\section{Other Perspectives}

Even though the mechanism of disease prevention is unknown, HT seems to be the most effective therapy of IBD currently proposed. As HT has its disadvantages, an important aim of HDPT research is to characterize the key molecules responsible for immunomodulation for use as drugs to control inflammation and autoimmune diseases such as IBD. For this reason, a number of international studies have attempted to identify the immune-active components of helminths. Some filarial nematode proteins such as cystatin (AvCystation) have been shown to prevent asthma and colitis by induction of IL-10 production by macrophages in animal models of the disease (Schnoeller et al., 2008). A filarial-derived phosphorylcholine product (ES-62) of Acanthocheilonema vitae modulates dendritic cell and macrophage activity in a toll-like receptor 4 (TLR-4) dependent manner and attenuates the symptoms of collagen-induced arthritis (CIA), aryl hydrocarbon receptor (AHR) knockout, and DSS-induced colitis (Goodridge et al., 2005). The recombinant $53 \mathrm{kDa}$ protein from $T$. spiralis prevents experimental colitis in mice and upregulates Th2 and regulatory cytokines while downregulating some Th1 cytokines (Du et al., 2011).

However, studies of the potential therapeutic use of single immune-active components isolated from nematode products is not as meaningful as previously suggested. The live nematodes express and secrete copious quantities of antigens into host tissues with different immunomodulatory properties, and the immunomodulatory effects, presumably intended for self-protection, must be multiple and complex. These mixtures of proteins, peptides, glycans and lipids might help the worm to survive in a number of ways, minimizing inflammatory processes or interfering with them, and selectively skewing the phenotype of the immune response generated (Mulyenna et al., 2009).

The protective immune responses to native antigens have been difficult to replicate based on recombinant antigens produced in most popular artificial expression systems, such as bacteria and yeast, as these usually have an incorrect conformation and the lack post-translational modifications of the recombinant molecule. Increasingly, post-translational modifications such as those including phosphocholine (PC) and various glycans are being recognized as the active components of many immunomodulatory components of helminths (ICHs), particularly in interactions with the host (Prasanphanich et al., 2013; Hokke et al., 2007). Furthermore, the use of bare single-defined immunomodulatory products as therapeutics is doomed to failure as such products can be neutralized and rendered ineffective by the host immune response. In addition, the use of helminth excretory secretory (ES) products does not solve the problem. These represent up to $30 \%$ of the proteome of an organism, and proteomic studies have found them to

Table 3. Cons and pros of using helminth therapy with live parasites.

\begin{tabular}{ll}
\multicolumn{2}{c}{ CONS } \\
\hline - Exposure to full spectrum of helminth products & - Strong immunogenic properties of live parasite \\
- Tissue invasion by helminths & - Better than any therapy currently available \\
- Ethical aspect & - An introduction to more extensive research using molecules \\
- Symptoms re-emergence after parasites removal & with immunomodulatory properties \\
- Tumor promoting activity & - Less expensive method \\
- Better adaptation of worms in colitis environment & \\
- Difficulty in proper placebo controls use & \\
\hline
\end{tabular}


Table 4. Comparison of effectiveness and safety of various ways of helminth therapy.

\section{EFFECTIVENESS}

\begin{tabular}{|c|c|c|c|}
\hline Live parasites & ES products & $\begin{array}{l}\text { Single parasite } \\
\text { compounds }\end{array}$ & $\begin{array}{l}\text { Synthetized proteins based } \\
\text { on parasite compounds }\end{array}$ \\
\hline
\end{tabular}

be highly distinct from somatic extracts (McSorley et al., 2013). However, the range of secretory products is wide and varied, comprising a complex mixture of many different substances with particular biological functions which are secreted from cells or glands, as well as various unnecessary metabolic products released from the body. Hence, it is difficult to determine the precise application of ES products from parasitic helminths: the analysis of the smaller molecules among ES products can be confounded by protein breakdown products and media components used for in vitro culture of nematodes, including amino acids with immunomodulatory properties in their own right. In addition, due to the low concentrations of protein caused by high dilutions of cultivation media, ES can often be contaminated by normally non-secreted proteins following nematode cell lysis and death (Smith et al., 2009).

Therefore, the somatic extract might be extremely useful in the development of intervention strategies for inflammatory reactions, especially since the immunomodulatory potency of helminths appears to be largely achieved by their surface glycoproteins (Erb, 2009). As the immune regulation induced during parasitic infection is complex and cannot be generated by single recombinant factors, and therapy with live nematodes could produce a severe infection, it appears essential to devise other modes of treatment with nematode products, acting as a silver bullet, particularly since a fully-effective treatment for autoimmune and allergic disease remains unknown (Table 4).

\section{Acknowledgments}

This work was supported by a grant from the National Science Center, POLAND No. 2011/01/M/NZ6/01793 and 2013/09/B/ NZ6/00653.

\section{References}

Adisakwattana, P., Nuamtanong, S., Kusolsuk, T., Chairoj, M., Yenchitsomanas, P.T., ChalsRI, U. (2013): Non-encapsulated Trichinella spp., T. papuae, diminishes severity of DSS-induced colitis in mice. Asian Pac. J. Allergy Immunol., 31: 106 - 114. DOI: 10.12932/AP0238.31.2.2013

Allen, J.E., Maizels, R.M. (2011): Diversity and dialogue in immunity to helminths. Nat. Rev. Immunol., 11: 375 - 388. DOI: 10.1038/ nri2992

Barthlott, T., Kassiotis, G., Stockinger, B. (2003): T cell regulation as a side effect of homeostasis and competition. J. Exp. Med., 197: 451 - 460. doi: 10.1084/jem.20021387
Bernstein, R.M. (2001): Injections and surgical therapy in chronic pain. Clin. J. Pain., 17: 94 - 104

Biedermann, L., Zeitz, J., Mwinyı, J., Sutter-Minder, E., Rehman, A., Ott, S. J., Steurer-Stey, C., Frei, A., Frei, P., Scharl, M., Loessner, M. J., Vavricka, S. R., Fried, M., Schreiber, S., Schuppler, M., RogleR, G. (2013) : Smoking cessation induces profound changes in the composition of the intestinal microbiota in humans. PLoS One, 8: e59260. DOI: 10.1371/journal.pone.0059260

Bilbo, S.D., Wray, G.A., Perkins, S.E., Parker, W. (2011): Reconstitution of the human biome as the most reasonable solution for epidemics of allergic and autoimmune diseases. Med. Hypotheses., 77: 494 - 504. DOI: 10.1016/j.mehy.2011.06.019

Blum, A.M., Hang, L., Setiawan, T.,. Urban, J.P., Stoyanoff, K.M., LEUNG, J., WeINSTOCK, J.V. (2012): Heligmosomoides polygyrus bakeri induces tolerogenic dendritic cells that block colitis and prevent antigen-specific gut T cell responses. J. Immunol., 189 (5): 2512 - 2520. DOI: 10.4049/jimmunol.1102892

Bodammer, P., Waitz, G., Loebermann, M., Holtfreter, M.C., Maletzki, C., Krueger, M.R., Nizze, H., Emmrich, J., Reisinger, E.C. (2011): Schistosoma mansoni infection but not egg antigen promotes recovery from colitis in outbred NMRI mice. Dig. Dis. Sci., 56: 70 - 78. DOI: 10.1007/s10620-010-1237-y

BrandtZaeg, P., Haraldsen, G., Rugtveit, J. (1997): Immunopathology of human inflammatory bowel disease. Springer Semin. Immunopathol., 18: 555 - 589. DOI: 10.1007/BF00824058

Broadhurst, M.J., Ardeshir, A., Kanwar, B., Mirpuri, J., Gundra, U.M., LeUng, J.M., Wiens, K.E., VuJKovic-CVIJIN, I., Kim, C.C., YAROVINSKY, F., LERChE, N.W., McCUNE, J.M., LOKE, P. (2012): Therapeutic helminth infection of macaques with idiopathic chronic diarrhea alters the inflammatory signature and mucosal microbiota of the colon. PLoS Pathog., 8: e1003000. DOI: 10.1371/journal. ppat. 1003000

Cader, M.Z., Kaser, A. (2013): Recent advances in inflammatory bowel disease: mucosal immune cells in intestinal inflammation. Gut, 62: 1653 - 1664. DOI: 10.1136/gutjnl-2012-303955

ChANDRASHEKARA, S. (2012): The treatment strategies of autoimmune disease may need a different approach from conventional protocol: A review. Indian J. Pharmacol., 44: 665 - 671. DOI: 10.4103/0253-7613.103235

Chassaing, B., Aitken, J.D., Malleshappa, M., Vijay-Kumar, M. (2015): Dextran sulfate sodium (DSS)-induced colitis in mice. Curr. Protoc. Immunol., 104: 15 - 25. DOI: 10.1002/0471142735. im1525s104

Chen, C.C., Louie, S., McCormick, B., Walker, W.A., Shi, H.N. (2005): Concurrent infection with an intestinal helminth parasite 
impairs host resistance to enteric Citrobacter rodentium and enhances Citrobacter-induced colitis in mice. Infect. Immun., 73: 5468 - 5481. DOI: 10.1128/IAI.73.9.5468-5481.2005

Chen, C.C., Louie, S., McCormick, B.A., Walker, W.A., Shi, H.N. (2006): Helminth primed dendritic cells alter the host response to enteric bacterial infection. J. Immunol.,176: 472 - 483

Cleynen, I., Boucher, G., Jostins, L. et al. (2016): Inherited determinants of Crohn's disease and ulcerative colitis phenotypes: a genetic association study. Lancet, 9, 156 - 167. DOI: 10.1016/ S0140-6736(15)00465-1

Correale, J. (2014): Helminth/Parasite treatment of multiple sclerosis. Curr. Treat Options Neurol.,16: 296. DOI: 10.1007/s11940014-0296-3

Croese, J., Giacomin, P., Navarro, S., Clouston, A., McCann, L., Dougall, A., Ferreira, I., Susianto, A., O'Rourke, P., Howlett, M., McCarthy, J., Engwerda, C., Jones, D., LoukAs, A. (2015): Experimental hookworm infection and gluten microchallenge promote tolerance in celiac disease. J. Allergy Clin. Immunol.,135: 508 516. DOI: 10.1016/j.jaci.2014.07.022

Croese, J., O'nell, J., Masson, J., Cooke, S., Melrose, W., Pritchard, D., SPEARE, R. (2006): A proof of concept study establishing Necator americanus in Crohn's patients and reservoir donors. Gut, 55: 136 - 137. doi: 10.1136/gut.2005.079129

Daveson, A.J., Jones, D.M., Gaze, S., McSorley, H., Clouston, A., Pascoe, A., Cooke, S., Speare, R., Macdonald, G.A., Anderson, R., McCarthy, J.S., LoukAS, A., Croese, J. (2011): Effect of hookworm infection on wheat challenge in celiac disease - a randomised double-blinded placebo controlled trial. PLoS One, 8: e17366. DOI: 10.1371/journal.pone.0017366

Donskow, K., Drela, N., Doligalska, M. (2011): Heligmosomoides bakeri antigen rescues CD4-positive T cells from glucocorticoid-induced apoptosis by Bcl-2 protein expression. Parasite Immunol., 33: 158 - 169. DOI: 10.1111/j.1365-3024.2010.01262.x

Donskow-Łysoniewska, K., Bien, J., Brodaczewska, K., Krawczak, K., DoligalsKa, M. (2013b): Colitis promotes adaptation of an intestinal nematode: a Heligmosomoides polygyrus mouse model system. PLoS One, 22: e78034. DOI: 10.1371/journal.pone.0078034

DONSKOW-ŁYSONIEWSKA, K., BRODACZEWSKA, K., DoligalSKA, M. (2013a): Heligmosomoides polygyrus antigens inhibit the intrinsic pathway of apoptosis by overexpression of survivin and Bcl-2 protein in CD4 T cells. Prion, 7: 319 - 327. DOI:10.4161/pri.25008 Donskow-Lysoniewska, K., Majewski, P., Brodaczewska, K., JozwicKA, K., DoligalsKa, M. (2012): Heligmosmoides polygyrus fourth stages induce protection against DSS induced colitis and change opioid expression in the intestine. Parasite Immunol., 34: 536 546. DOI: 10.1111/pim.12003

Du, L., Tang, H., Ma, Z., Xu, J., Gao, W., Chen, J., Gan, W., Zhang, Z., Yu, X., Zноu, X., Hu, X. (2011): The protective effect of the recombinant 53-kDa protein of Trichinella spiralis on experimental colitis in mice. Dig. Dis. Sci., 56: 2810 - 2817. DOI: 10.1007/ s10620-011-1689-8

Elliott, D.E., Li, J., Blum, A., Metwali, A., Qadir, K., Urban, J.F. JR,
WeINSTOCK, J.V. (2003): Exposure to schistosome eggs protects mice from TNBS-induced colitis. Am. J. Physiol. Gastrointest. Liver Physiol., 284: G385 - G391. DOI: 10.1152/ajpgi.00049.2002 Elliott, D.E., Metwali, A., Leung, J., Setiawan, T., Blum, A.M., InCe, M.N., Bazzone, L.E., Stadecker, M.J., URBan, J.F. JR, Weinstock, J.V. (2008): Colonization with Heligmosomoides polygyrus suppresses mucosal IL-17 production. J. Immunol., 181: 2414 - 2419 Elliott, D.E., Setiawan, T., Metwalı, A., Blum, A., Urban, J.F. JR., WEINSTOCK, J.V. (2004): Heligmosomoides polygyrus inhibits established colitis in IL-10-deficient mice. Eur. J. Immunol., 34: 2690 - 2698. DOI: 10.1002/eji.200324833

Elliott, D.E., Urban, J.F. JR., Argo, C.K., Weinstock, J.V. (2000): Does the failure to acquire helminthic parasites predispose to Crohn's disease? FASEB J., 14: 1848 - 1855. doi: 10.1096/fj.990885hyp

ERB, K.J. (2009): Can helminths or helminth-derived products be used in humans to prevent or treat allergic diseases? Trends Immunol., 30: 75 - 82. DOI: 10.1016/j.it.2008.11.005

FINLAY, C.M., Walsh, K.P., MILLS, K.H. (2014): Induction of regulatory cells by helminth parasites: exploitation for the treatment of inflammatory diseases. Immunol. Rev., 259: 206 - 230. DOI: 10.1111/imr.12164

Fleming, J.O., Isaak, A., Lee, J.E., Luzzio, C.C., Carrithers, M.D., Cook, T.D., Field, A.S., Boland, J., Fabry, Z. (2011): Probiotic helminth administration in relapsing-remitting multiple sclerosis: a phase 1 study. Mult. Scler., 17: 743 - 754. DOI: 10.1177/1352458511398054

Goodridge, H.S., Stepek, G., Harnett, W., Harnett, M.M. (2005): Signalling mechanisms underlying subversion of the immune response by the filarial nematode secreted product ES-62. Immunology, 115: 296 - 304. DOI: 10.1111/j.1365-2567.2005.02167.x Gouy De Bellocq, J., Ferte, H., Depaquit, J., Justine, J.L., Tillier, A., Durette-Desset, M.C. (2001): Phylogeny of the Trichostrongylina (Nematoda) inferred from 28S rDNA sequences. Mol. Phylogenet. Evol., 19: 430 - 442. DOI: 10.1006/mpev.2001.0925

Hadis, U., Wahl, B., Schulz, O., HardTKe-Wolenski, M., Schippers, A., Wagner, N., Müller, W., Sparwasser, T., Förster, R., Pabst, O. (2011): Intestinal tolerance requires gut homing and expansion of FoxP3+ regulatory T cells in the lamina propria. Immunity, 34: 237 - 246. DOI: 10.1016/j.immuni.2011.01.016

Hang, L., Setiawan, T., Blum, A.M., Urban, J., Stoyanoff, K., ArihlRO, S., ReIneCKer, H.C., Weinstock, J.V. (2010): Heligmosomoides polygyrus infection can inhibit colitis through direct interaction with innate immunity. J. Immunol, 185: 3184 - 3189. DOI: 10.4049/jimmunol.1000941

HeLmBY, H. (2015): Human helminth therapy to treat inflammatory disorders - where do we stand? BMC Immunol., 16: 12. DOI: 10.1186/s12865-015-0074-3

Herrera, L.A., Ostrosky-Wegman, P. (2001): Do helminths play a role in carcinogenesis? Trends Parasitol., 17: 172 - 175. DOI: 10.1016/S1471-4922(00)01942-5

Hokke, C.H., Deelder, A.M., Hoffmann, K.F., Wuhrer, M. (2007): 
Glycomics-driven discoveries in schistosome research. Exp. Parasitol., 117: 275 - 283. DOI: 10.1016/j.exppara.2007.06.003

Huby, F., Hoste, H., Mallet, S., Fournel, S., Nano, J.L. (1995): Effects of the excretory/secretory products of six nematode species, parasites of the digestive tract, on the proliferation of HT29-D4 and HGT-1 cell lines. Epithelial Cell Biol., 4: 156 - 162

Hunter, M.M., Wang, A., HIROTA, C.L., Mckay, D.M. (2005): Neutralizing anti-IL-10 antibody blocks the protective effect of tapeworm infection in a murine model of chemically induced colitis. J. Immunol.,174: 7368 - 7375. DOI: 10.4049/jimmunol.174.11.7368

Hunter, M.M., Wang, A., Mckay, D.M. (2007): Helminth infection enhances disease in a murine TH2 model of colitis. Gastroenterology, 132: 1320 - 1330. DOI: 10.1053/j.gastro.2007.01.038

Ince, M.N., Elliott, D.E., Setiawan, T., Metwali, A., Blum, A., Chen, H.L., URBan, J.F., FlavelL, R.A., Weinstock, J.V. (2009): Role of T cell TGF-beta signaling in intestinal cytokine responses and helminthic immune modulation. J. Immunol., 39: 1870 - 1878. DOI: 10.1002/eji.200838956

Kappus, K.D., Lundgren, R.G. JR., JuRAnek, D.D., Roberts, J.M., SPENCER, H.C. (1994): Intestinal parasitism in the United States: update on a continuing problem. Am. J. Trop. Med. Hyg., 50, 705 - 713. DOI: 10.4269/ajtmh.1994.50.705

Keubler, L.M., Buettner, M., Häger, C., Bleich, A. (2015): A multihit model: colitis lessons from the Interleukin-10-deficient mouse. Inflamm. Bowel Dis., 2: 1967 - 1975. DOI: 10.1097/ MIB.0000000000000468

KHAN, A.R., FALLON, P.G. (2013): Helminth therapies: translating the unknown unknowns to known knowns. Int. J. Parasitol., 43: 293 299. DOI: 10.1016/j.jpara.2012.12.002

Khan, W.I., Blennerhasset, P.A., Varghese, A.K., Chowdhury, S.K., Omsted, P., Deng, Y., Collins, S.M. (2002): Intestinal nematode infection ameliorates experimental colitis in mice. Infect. Immun., 70: 5931 - 5937. doi: 10.1128/IAl.70.11.5931-5937.2002

LAKATOS, P.L. (2006): Recent trends in the epidemiology of inflammatory bowel diseases: up or down? World J. Gastroenterol., 14: 6102-6108. doi: 10.3748/wjg.v12.i38.6102

Leitner, G.C., Vogelsang, H. (2016): Pharmacological-and non-pharmacological therapeutic approaches in inflammatory bowel disease in adults. World J. Gastrointest. Pharmacol. Ther., 6: 5 - 20. DOI: 10.4292/wjgpt.v7.i1.5

LeONG, R.W., Mitrev, N., Ko, Y. (2016): Hygiene hypothesis: Is the evidence the same all over the world? Dig. Dis., 34: 35 - 42. DOI: 10.1159/000442922

Leung, J., Hang, L., Blum, A., Setiawan, T., Stoyanoff, K., Weinstock, J. (2012): Heligmosomoides polygyrus abrogates antigen-specific gut injury in a murine model of inflammatory bowel disease. Inflamm. Bowel Dis., 18: 1447 - 1455. DOI: 10.1002/ibd.22858

LI, X., Sundquist, J., Hemminki, K., Sundquist, K. (2011): Risk of inflammatory bowel disease in firstand second-generation immigrants in Sweden: a nationwide follow-up study. Inflamm. Bowel Dis., 17: 1784 - 1791. DOI: 10.1002/ibd.21535

MacDonald, T.T., Monteleone, G. (2005): Immunity, inflammation, and allergy in the gut. Science, 25: 1920 - 1925. DOI: 10.1126/ science. 1106442

Maizels, R.M., Balic, A., Gomez-Escobar, N., Nair, M., Taylor, M.D., Allen, J.E. (2004): Helminth parasites - masters of regulation. Immunol. Rev., 201, 89 - 116. DOI: 10.1111/j.01052896.2004.00191.x

Maizels, R.M., Hewitson, J.P., Smith, K.A. (2012): Susceptibility and immunity to helminth parasites. Curr. Opin. Immunol., 24: 459 - 466. DOI: 10.1016/j.coi.2012.06.003

MANN, E.R., LI, X. (2014): Intestinal antigen-presenting cells in mucosal immune homeostasis: crosstalk between dendritic cells, macrophages and B-cells. World J. Gastroenterol., 7: 9653 9664. DOI: 10.3748/wjg.v20.i29.9653

McGuckin, M.A., ERI, R., Simms, L.A., FloRin, T.H., RAdFORd-Smith, G. (2009): Intestinal barrier dysfunction in inflammatory bowel diseases. Inflamm. Bowel Dis., 15: 100 - 113. DOI: 10.1002/ ibd.20539

McSorley, H.J., Hewitson, J.P., Maizels, R.M. (2013): Immunomodulation by helminth parasites: defining mechanisms and mediators. Int. J. Parasitol., 43: 301 - 310. DOI: 10.1016/j.ijpara.2012.11.011

Melon, A., Wang, A., Phan, V., Mckay, D.M. (2010): Infection with Hymenolepis diminuta is more effective than daily corticosteroids in blocking chemically induced colitis in mice. J. Biomed. Biotechnol., 384523. DOI: 10.1155/2010/384523

Metwali, A., Setiawan, T., Blum, A.M., Urban, J., Elliott, D.E., Hang, L., WeINSTOCK, J.V. (2006): Induction of CD8+ regulatory T cells in the intestine by Heligmosomoides polygyrus infection. Am. J. Physiol. Gastrointest. Liver Physiol., 291: G253 - G259. DOI: 10.1152/ajpgi.00409.2005

Molodecky, N.A., Soon, I.S., Rabi, D.M., Ghali, W.A., Ferris, M., Chernoff, G., Benchimol, E.I., Panaccione, R., Ghosh, S., Barkema, H.W., KaPLAN, G.G. (2012): Increasing incidence and prevalence of the inflammatory bowel diseases with time, based on systematic review. Gastroenterology, 142: 46 - 54. DOI: 10.1053/j.gastro.2011.10.001

MonRoy, F.G., EnRIQUEZ, F.J. (1992): Heligmosomoides polygyrus: a model for chronic gastrointestinal helminthiasis. Parasitol. Today, 8: 49 - 54. DOI: 10.1016/0169-4758(92)90084-F

Morampudi, V., Bhinder, G., Wu, X., Dal, C., Sham, H.P., Vallance, B.A., JACOBSON, K. (2014): DNBS/TNBS colitis models: providing insights into inflammatory bowel disease and effects of dietary fat. J. Vis. Exp., 84: 51297. DOI:10.3791/51297

Moreels, T.G., NieuwendiJk, R.J., De Man, J.G., De Winter, B.Y., Herman, A.G., Van Marck, E.A., Pelckmans, P.A. (2004): Concurrent infection with Schistosoma mansoni attenuates inflammation induced changes in colonic morphology, cytokine levels, and smooth muscle contractility of trinitrobenzene sulphonic acid induced colitis in rats. Gut, 53: 99 - 107

Mulvenna, J., Hamilton, B., Nagaraj, S.H., Smyth, D., Loukas, A., GoRman, J.J. (2009): Proteomics analysis of the excretory/secretory component of the blood-feeding stage of the hookworm, 
Ancylostoma caninum. Mol. Cell. Proteomics, 8: 109 - 121. DOI: 10.1074/mcp.M800206-MCP200

NieWiadomski, O., Studd, C., Wilson, J., Williams, J., Hair, C., Knight, R., Prewett, E., Dabkowski, P., Alexander, S., Allen, B., Dowling, D., Connell, W., Desmond, P., Bell, S. (2016): Influence of food and lifestyle on the risk of developing inflammatory bowel disease. Intern. Med. J. , 46: 669 - 676. DOI: 10.1111/imj.13094

Packham, G., Stevenson, F.K. (2005): Bodyguards and assassins: $\mathrm{Bcl}-2$ family proteins and apoptosis control in chronic lymphocytic leukaemia. Immunology, 114: 441 - 449. DOI: 10.1111/j.13652567.2005.02117.x

Prasanphanich, N.S., Mickum, M.L., Heimburg-Molinaro, J., CumMINGS, R.D. (2013): Glycoconjugates in host-helminth interactions. Front. Immunol., 4: 240. DOI: 10.3389/fimmu.2013.00240

Probert, C.S., Jayanthi, V., Pinder, D., Wicks, A.C., Mayberry, J.F. (1992): Epidemiological study of ulcerative proctocolitis in Indian migrants and the indigenous population of Leicestershire. Gut, 33: $687-693$

Reardon, C., Sanchez, A., Hogaboam, C.M., Mckay, D.M. (2001): Tapeworm infection reduces epithelial ion transport abnormalities in murine dextran sulfate sodium induced colitis. Infect. Immun., 69: 4417 - 4423. doi: 10.1128/IAI.69.7.4417-4423.2001

Rescigno, M., Di Sabatino, A. (2009): Dendritic cells in intestinal homeostasis and disease. J. Clin. Invest.,119: 2441 - 2450. DOI: 10.1172/JCI39134

Ruyssers, N.E., De Winter, B.Y., De Man, J.G., Loukas, A., Herman, A.G., Pelckmans, P.A., Moreels, T.G. (2008): Worms and the treatment of inflammatory bowel disease: are molecules the answer? Clin. Dev. Immunol., 567314. DOI: 10.1155/2008/567314

Samuelsson, S. (1976): Ulceros Colit och Proktit [Colitis Ulcerosa and Inflammantion]. University of Uppsala, Uppsala, Sweden (In Swedish)

SandBorn, W.J., Elliott, D.E., Weinstock, J., Summers, R.W., LANdry-Wheeler, A., Silver, N., Harnett, M.D., Hanauer, S.B. (2013): Randomised clinical trial: the safety and tolerability of Trichuris suis ova in patients with Crohn's disease. Aliment. Pharmacol. Ther., 38: 255 - 263. DOI: 10.1111/apt.12366

Satsangl, J., Silverberg, M.S., Vermeire, S., Colombel, J.F. (2006): The Montreal classification of inflammatory bowel disease: controversies, consensus, and implications. Gut, 55: 749 - 753. DOI: 10.1136/gut.2005.082909

Schnoeller, C., Rausch, S., Pillai, S., Avagyan, A., Wittig, B. M., Loddenkemper, C., Hamann, A., Hamelmann, E., Lucius, R., HartMANN, S. (2008): A helminth immunomodulator reduces allergic and inflammatory responses by induction of $\mathrm{IL}-10$-producing macrophages. J. Immunol., 15: 4265 - 4272. DOI: 10.4049/jimmunol.180.6.4265

Setiawan, T., Metwali, A., Blum, A.M. Nedim Ince, M., Urban Jr., J.F., Elııott, D.E., Weinstock, J.V. (2007): Heligmosomoides polygyrus promotes regulatory T-cell cytokine production in the mu- rine normal distal intestine. Infect. Immun., 75: 4655 - 4663. DOI: 10.1128/IAI.00358-07

Shorter, R.G., Huizenga, K.A., Spencer, R.J. (1972): A working hypothesis for the etiology and pathogenesis of nonspecific inflammatory bowel disease. Am. J. Dig. Dis., 17: 1024 - 1032

Smith, P., Mangan, N.E., Fallon, P.G. (2009): Generation of parasite antigens for use in Toll-like receptor research. Methods Mol., 517: 401 - 413. DOI: 10.1007/978-1-59745-541-1_24

Smith, P., Mangan, N.E., Walsh, C.M., Fallon, R.E., Mckenzie, A.N.J., VAn RoolJen, N., FALlon, P.G. (2007): Infection with a helminth parasite prevents experimental colitis via a macrophage-mediated mechanism. J. Immunol., 178: 4557 - 4566. DOI: 10.4049/ jimmunol.178.7.4557

StRACHAN, D.P. (1989): Hay fever, hygiene and household size. BMJ, 299: $1259-1260$

Summers, R.W., Elliott, D.E., QAdir, K., URban, J.F., ThOmpson, R., Weinstock, J.V. (2003): Trichuris suis seems to be safe and possibly effective in the treatment of inflammatory bowel disease. Am. J. Gastroenterol., 98, 2034 - 2041. DOI: 10.1111/j.15720241.2003.07660.x

Summers, R.W., ElLIOTt, D.E., URBan, J.F. JR., ThOMPSON, R., WeINSTоck, J.V. (2005a): Trichuris suis therapy in Crohn's disease. Gut, 54: 87 - 90. DOI: 10.1136/gut.2004.041749

Summers, R.W., Elliott, D.E., URBAn, J.F. JR., Thompson, R.A., WEINSTOCK, J.V. (2005b): Trichuris suis therapy for active ulcerative colitis: a randomized controlled trial. Gastroenterology, 128: 825 832. DOI: 10.1053/j.gastro.2005.01.005

Sutton, T.L., Zhao, A., Madden, K.B., Elfrey, J.E., Tuft, B.A., Sullivan, C.A., URBAn, JR., J.F., Shea-Donohue, T. (2008): Antiinflammatory mechanisms of enteric Heligmosomoides polygyrus infection against trinitrobenzene sulfonic acid-induced colitis in a murine model. Infect. Immun., 76: 4772 - 4782. DOI: 10.1128/IAI.00744-07 Taylor, M.D., Van Der Werf, N., Maizels, R.M. (2012): T cells in helminth infection: the regulators and the regulated. Trends Immunol., 33: 181 - 189. DOI: 10.1016/j.it.2012.01.001

WiLSON, M.S., MaIzeLS, R.M. (2004): Regulation of allergy and autoimmunity in helminth infection. Clin. Rev. Allergy Immunol., 26: 35 - 50. DOI: 10.1385/CRIAI:26:1:35

WIRTZ, S., NeURATH, M.F. (2007): Mouse models of inflammatory bowel disease. Adv. Drug Deliv. Rev., 59: 1073 - 1083. DOI: 10.1016/j.addr.2007.07.003

XIA, C.M., ZHAO, Y., JIANG, L., JIANG, J., ZHANG, S.C. (2011): Schistosoma japonicum ova maintains epithelial barrier function during experimental colitis. World J Gastroenterol., 17: 4810 - 4816.

ZhaO, Y., Zhang, S., Jiang, L., Jiang, J., LiU, H. (2009): Preventive effects of Schistosoma japonicum ova on trinitrobenzenesulfonic acid-induced colitis and bacterial translocation in mice. J. Gastroenterol. Hepatol., 24: 1775 - 1780. DOI: 10.1111/j.14401746.2009.05986.x 